\title{
PENGARUH KEMAMPUAN ABSTRAK DAN KEMAMPUAN NUMERIK TERHADAP PRESTASI BELAJAR MATEMATIKA KELAS XI IPA SMA SEKABUPATEN BOGOR
}

\author{
MOHAMAD TAOFIK \\ SMA Negeri Tajurhalang, Bogor, Jawa Barat \\ E-maial : opikcamuhe@yahoo.com
}

\begin{abstract}
ABSTRAK
Tujuan dari penelitian ini adalah untuk mengetahui: (1) Pengaruh kemampuan abstrak terhadap prestasi belajar matematika, (2) Pengaruh kemampuan numerik terhadap prestasi belajar matematika (3) Pengaruh kemampuan abstrak dan kemampuan numerik terhadap prestasi belajar matematika. Metode yang digunakan dalam penelitian ini adalah metode deskriptif. Data yang digunakan melalui teknik tes dan menggunakan analisis kuantitatif $\mathrm{r} 1=$ 0,547, menunjukan bahwa kemampuan abstrak dan prestasi belajar matematika mempunyai korelasi yang cukup berarti, kemampuan abstrak berpengaruh terhadap prestasi belajar matematika sebesar 29,92\%. Hasil pengujianuji hipotesis didapat $\mathrm{Zo}>\mathrm{Zt}$ atau 9,46 > 1,96 berarti ada pengaruh yang signifikan antara kemampuan abstrak dengan prestasi belajar matematika. Pengaruh tersebut dapat dinyatakan dalam persamaan regresi $Y=29,1+0,325 \mathrm{X} 1$. r2 $=0,593$ berarti kemampuan numerik dan prestasi belajar matematika mempunyai korelasi positif yang cukup berarti, kemampuan numerik berpengaruh terhadap prestasi belajar matematika sebesar 35,17\%. Hasil pengujian hipotesis didapat $\mathrm{Zo}>\mathrm{Zt}$ atau 10,25 $>1,96$ berarti ada pengaruh yang signifikan antara kemampuan numerik dengan prestasi belajar matematika Pengaruh tersebut dapat dinyatakan dalam persamaan regresi $Y=21,8+0,384 X 2$. $r 12 y=0,691$, menunjukan bahwa kemampuan abstrak dan kemampuan numerik secara bersama-sama mempunyai korelasi positif yang cukup berarti, dan memberikan pengaruh terhadap prestasi belajar matematika sebesar 74,75\%. Hasil pengujian hipotesis didapat Fo > Ft atau 119,5 > 3,04 berarti terdapat pengaruh yang signifikan antara kemampuan abstrak dan kemampuan numerik dengan prestasi belajar matematika. Pengaruh tersebut dapat dinyatakan dalam persamaan regresi $\mathrm{Y}=10,2+0,205 \mathrm{X} 1+0,280 \mathrm{X} 2$.
\end{abstract}

Kata Kunci: Kemampuan Abstrak, Kemampuan Numerik dan Prestasi Belajar matematika.

\section{PENDAHULUAN}

Salah satu tantangan yang harus dihadapi dalam proses pembelajaran matematika adalah keterkaitannya dengan bidang lain seperti teknologi, budaya, dan ekonomi serta tuntutan untuk mengembangkan matematika sebagai program dan paket pendidikan yang dapat mempersiapkan anak didik guna menghadapi persaingan dimasa mendatang. Sejak digulirkannya kurikulum berbasis kompetensi (KBK) pada tahun 2006 semua guru matematika telah menentukan batas atau Kriteria Ketuntasan Minimum (KKM) tetapi dalam kenyataannya, dalam pelajaran matematika masih banyak siswa yang tidak dapat mencapai KKM tersebut, baik dalam satu Kompetensi Dasar (KD) maupun beberapa KD bahkan untuk satu standar kompetensi (SK). Selain unsur-unsur daya dukung sekolah dan kompleksitas yang digunakan untuk menentukan KKM matematika, yang lebih penting adalah unsur intik siswa atau kecerdasan siswa itu sendiri, yang biasa disebut dengan IQ (Intelegensi Quotein).

Matematika merupakan salah satu pelajaran utama baik ditingkat SD, SMP, Maupun SMA. Pembelajaran matematika merupakan salah satu kajian menarik untuk dibahas karena memiliki perbedaan karakteristik yang diajarkan pada tingkat pendidikan menengah dan pendidikan atas. Matematika adalah ilmu deduktif, aksiomatik, formal, hirarkis, abstrak, bahasa symbol yang padat arti. Sedangkan pola berfikir anak didik sangat bervariasi dalam tahapan kongkrit kepemikiran abstrak. Untuk itu diperlukan jembatan yang dapat menetralkan perbedaan atau pertentangan tersebut. 
Keberhasilan proses belajar mengajar matematika dapat diukur dari keberhasilan siswa yang mengikuti kegiatan tersebut. Keberhasilan itu dapat dilihat dari tingkat pemahaman, penguasaan materi serta prestasi belajar siswa. Semakin tinggi pemahaman dan penguasaan materi serta prestasi belajar maka semakin tinggi pula tingkat keberhasilan pembelajaran. Namun kenyataannya dapat dilihat bahwa prestasi belajar matematika yang dicapai siswa masih rendah. Prestasi belajar siswa mampu memperlihatkan perubahan-perubahan dalam bidang pengetahuan/pengalaman dalam bidang ketrampilan, nilai dan sikap. Prestasi belajar matematika adalah hasil yang dapat dicapai oleh seseorang setelah melakukan kegiatan belajar matematika dalam kurun waktu tertentu. Jadi prestasi belajar matematika merupakan hasil belajar yang dicapai oleh siswa setelah mempelajari matematika dalam kurun waktu tertentu dan diukur dengan menggunakan alat evaluasi (tes).

Faktor-faktor yang diduga dapat mempengaruhi rendahnya prestasi belajar matematika adalah masalah fasilitas belajar siswa. Sebagai rumpun dalam pelajaran MIPA (Matematika dan Ilmu Pengetahuan Alam) yang terdiri dari pelajaran matematika, fisika, kimia dan biologi, ternyata hampir di seluruh sekolah untuk pelajaran matematika tidak memiliki laboratorium yang khusus seperti pelajaran MIPA lainnya, sarana prasarana atau fasilitas dalam pembelajaran matematika umumnya masih kurang, padahal fasilitas belajar ini dapat mempengaruhi prestasi belajar matematika. Demikian juga di SMA Negeri di Kabupaten Bogor, laboratorium untuk matematika tidak pernah diusahan keberadaannya bahkan bantuan dari dinas pendidikan pun untuk penyediaan laboratorium matematika hampir tidak ada.

Faktor yang diduga menyebabkan rendahnya prestasi belajar matematika lainnya yang dihadapi siswa SMA timbul setelah ada kebijakan yang melarang penjualan buku pegangan siswa atau teks book sehingga siswa mendapatkan materi pelajaran yang terbatas atau minimal, sedangkan kemampuan siswa untuk membeli buku pegangan tersebut di luar sekolah sangat kurang, karena tingkat ekonomi siswa SMA pada umumnya kurang.

Pembelajaran matematika berfungsi mengembangkan kemampuan berkomunikasi dengan menggunakan bilangan dan symbol-symbol serta ketajaman penalaran yang dapat membantu memperjelas dalam menyelesaikan permasalahan kehidupan sehari-hari. Dengan demikian dari berbagai kemampuan tersebut di atas yang sangat banyak kaitannya dengan matematika adalah tes kemampuan numerik(numerical abillity). Tes ini dirancang untuk mengungkap pemahaman seseorang atas relasi angka dan konsep-konsep menurut angkaangka. Subtes yang termasuk dalam numerical abillity adalah deret angka, angka berkolom, matematika, kecepatan berhitung, dan matematika bergambar.

Belajar matematika termasuk jenis belajar abstrak yang menggunakan cara-cara berpikir abstrak. Tujuan nya adalah untuk memperoleh pemahaman dan pemecahan masalahmasalah yang tidak nyata. Dalam mempelajari hal-hal yang abstrak diperlukan peranan akal yang kuat di samping penguasaan atas prinsip, konsep, dan generalisasi. Dengan demikian peranan tes kemampuan abstrak atau penalaran abstrak (Abstract Reasoning) dalam pelajaran matematika juga sangat diperlukan. Tes ini untuk mengungkap bagaimana sebaiknya seseorang memahami ide-ide yang tidak dinyatakan dengan kata-kata atau angka-angka, dan melihat bagaimana seseorang dapat memikirkan masalah-masalah, sekalipun tanpa petunjuk yang berbentuk kata-kata. Dengan kemampuan abstrak ini diharapkan siswa dapat cepat menguasai prinsip dan konsep yang diajarkan dalam matematika serta dapat membuat generalisasi dari prinsip dan konsep dalam matematika tersebut.

Pada umumnya SMA Negeri di kabupaten Bogor tiap tahunnya mengadakan tes kemampuan numerik dan kemampuan abstrak, yang biasanya diadakan pada pertengahan semester dua di kelas satu atau kelas X. Dalam pelaksanaannya pihak sekolah bekerjasama dengan lembaga lain penyelenggara Tes Psikologi, yang hasilnya digunakan dalam menentukan jurusan IPA yang diampu oleh siswa walaupun masih dipengaruhi oleh keinginan dan desakan orang tua siswa. Hal inilah yang mendorong penulis untuk mengadakan penelitian apakah kemampuan numerik dan kemampuan abstrak berpengaruh terhadap prestasi matematika siswa SMA Negeri se Kabupaten Bogor 


\section{METODE PENELITIAN}

\section{Metode Penelitian}

Metode penelitian yang digunakan dalam penelitian ini adalah metode survei dengan pendekatan studi korelasional dan metode deskriptif. Yaitu, suatu prosedur pemecahan masalah yang diselidiki dengan menggambarkan atau melukiskan keadaan objek penelitian pada saat sekarang berdasarkan fakta-fakta yang ada atau sebagaimana adanya.

\section{Populasi dan Teknik Penentuan Sampel Penelitian}

1. Populasi Penelitian

Populasi adalah keseluruhan objek penelitian yang dapat terdiri dari manusia, benda-benda, tumbuh-tumbuhan, gejala-gejala, nilai-nilai tes, atau peristiwa-peristiwa sebagai sumber data yang memiliki karakteristik tertentu dalam suatu penelitian (Nawawi, 2001: 141). Populasi dalam penelitian ini adalah seluruh siswa kelas XI IPA semester II, SMA Negeri se Kabupaten Bogor tahun pelajaran 2009/2010, yang berjumlah 35 SMA Negeri dengan jumlah siswa XI IPA seluruhnya 3272. Dengan ketentuan bahwa siswa tersebut telah mengikuti tes kemampuan abstrak dan tes kemampuan numerik serta menerima pembelajaran matematika dan mengikuti tes sumatif serta telah mendapat nilai raport. Pemilihan populasi ini pun dipertimbangkan pada terpenuhinya variabel yang diperlukan dalam penelitian.

2. Sampel Penelitian

Sampel adalah sebagian dari populasi yang dijadikan responden. Populasi target dalam penelitian ini berjumlah 1263 siswa. Dari populasi target ini, peneliti mengambil sampel dengan menggunakan rumus:

$$
\mathrm{n}=\frac{N}{N(d)^{2}+1}
$$

Keterangan:

$\mathrm{n}=$ jumlah sampel

$\mathrm{N}=$ Populasi

$\mathrm{d}=$ Taraf nyata $(5 \%)$ (Jonathan Sarwono : 2006)

Dari rumus di atas didapat jumlah responden sebanyak 300 orang. Teknik yang digunakan dalam penentuan sampel penelitian ini adalah random sampling dengan langkah pemberian nomor urut kepada semua calon responden kemudian dengan melihat tabel bilangan acak calon responden mendapat nomor sebagai responden.

3. Teknik Pengambilan Sampel

Pengambilan sampel dilakukan dengan cara Multi Stage Sampling yaitu pengambilan sampel dengan beberapa tahap yaitu:

a. Menentukan populasi yaitu seluruh siswa SMA Negeri se Kabupanen Bogor.

b. Menentukan SMA Negeri se Kabupaten Bogor yang mengadakan tes kemampuan abstrak dan tes kemampuan numerik.

c. Menentukan kelas yang akan dijadikan sampel

Kelas yang dijadikan sampel dalam penelitian ini adalah kelas XI IPA dari masingmasing SMA yang terpilih dalam tahap ke dua.

d. Menentukan sekolah yang dijadikan target populasi penelitian

Karena luasnya daerah Kabupaten Bogor yang terbagi menjadi 4 wilayah yaitu Wilayah Bogor Barat, Bogor Timur, Bogor Utara dan Bogor Selatan. serta keterbatasan dari penulis, maka dari 15 SMA yang telah terpilih pada tahap ke tiga penulis hanya memilih 8 sekolah saja yang menjadi target sampel penelitian dengan masih mempertimbangkan bahwa SMA yang terpilih masih mewakili keempat wilayah tersebut,

e. Menentukan sampel penelitian

Dengan melihat tabel bilangan acak calon responden mendapat nomor sebagai responden. Teknik Pengambilan sampel dengan menggunakan tabel random dengan angka terkecil 0001 dan angka terbesar 9999. 


\section{Metode Pengumpulan Data}

1. Variabel Penelitian

Variabel dalam penelitian ini terdiri dari dua variabel bebas (X1 dan X2) dan satu variabel terikat (Y), yaitu:

a. Variabel Bebas:

X1 : Kemampuan abstrak siswa kelas XI IPA

$\mathrm{X} 2$ : Kemampuan numerik siswa kelas XI IPA

b. Variabel Terikat

Y : Prestasi belajar matematika siswa kelas XI IPA

2. Sumber Data

Data untuk kemampuan abstraksi dan kemampuan numerik bersumber dari hasil tes intelegensi yang diselenggarakan di setiap SMA Sekabupaten Bogor, sedangkan data prestasi belajar matematika bersumber dari hasil ulangan umum semester I I siswa kelas XI IPA SMA se Kabupaten Bogor.

3. Teknik Pengambilan Data

Teknik penelitian merupakan alat kerja yang menjadi pelengkap metode penelitian . Teknik yang digunakan dalam penelitian ini adalah teknik dokumentasi dan teknik tes.

a. Teknik Dokumentasi

Teknik dokumentasi digunakan penulis untuk mendapatkan data tentang kemampuan abstrak dan kemampuan numerik dengan cara meminta data kepada guru-guru BP yang menjadi target populasi yaitu sebanyak 8 SMA Negeri se Kabupaten Bogor.

b. Teknik Tes

Teknik tes akademik digunakan penulis untuk memperoleh data tentang prestasi belajar siswa dalam pelajaran matematika, jenis tes yang digunakan dalam penelitian ini pilihan ganda biasa dengan 25 soal dan essay 5 soal. Tes dilakukan pada tanggal 9 Juni 2010 di semua SMA Negeri yang dijadikan target populasi, penulis dibantu oleh semua guru matematika kelas XI IPA di SMA tersebut sampai pada perolehan skor tiap-tiap siswa.

\section{HASIL DAN PEMBAHASAN}

\section{Pengaruh Antara Kemampuan Abstrak (X1) Terhadap Prestasi Belajar Matematika} (Y)

Penelitian secara empiris yang dilakukan terhadap 300 orang siswa Kelas XI IPA se Kabupaten Bogor menunjukan hubungan yang positif dan signifikan antara kemampuan abstrak dengan prestasi belajar matematika dan memiliki koefesien korelasi sebesar 0,547. Hal ini menunjukan bahwa bila seorang siswa mempunyai kemampuan abstrak yang baik maka akan mempunyai prestasi belajar matematika yang baik pula. Kemampuan abstrak memberikan pengaruh terhadap prestasi belajar matematika sebesar $29,92 \%$. Hasil pengujian hipotesis koefesien korelasi didapat bahwa terdapat hubungan yang signifikan antara kemampuan abstrak dengan prestasi belajar matematika kelas XI IPA SMA se Kabupaten Bogor.

Pengaruh kemampuan abstrak (X1) terhadap prestasi belajar matematika (Y) siswa kelas XI IPA SMA se Kabupaten Bogor dapat dinyatakan dalam persamaan regresi linear $\mathbf{Y}$ atas X1 yaitu $\mathbf{Y}=\mathbf{2 9 , 1}+\mathbf{0 , 3 2 5} \mathrm{X1}$. Dengan koefesien dari X1 bernilai positif yaitu (+ $0,325)$, berarti bahwa setiap penambahan satu skor kemampuan abstrak akan menambah skor prestasi belajar matematika sebesar 0,325. dengan skor terkecilnya adalah 29,1. Dengan demikian dapat diartikan bahwa peningkatan skor prestasi belajar matematika dipengaruhi oleh kemampuan abstrak, atau dengan kata lain bahwa makin baik kemampuan abstrak seorang siswa akan makin baik pula prestasi belajar matematikanya.

Hasil pengujian hipotesis tentang kelinieran regresi dan keberartian koefesien regresi didapat bahwa persamaan $\mathbf{Y}=\mathbf{2 9 , 1}+\mathbf{0 , 3 2 5}$ X1 berbentuk linier dan koefesiennya 
signifikan (nyata/berarti). Jadi Hipotesis penelitian yaitu: "Terdapat pengaruh antara kemampuan abstrak dengan prestasi belajar matematika siswa" telah terbukti.

\section{Pengaruh Antara Kemampuan Numerik (X2) Terhadap Prestasi Belajar Matematika} (Y)

Penelitian secara empiris yang dilakukan terhadap 300 orang siswa Kelas XI IPA se Kabupaten Bogor menunjukan hubungan yang positif dan signifikan antara kemampuan numerik dengan prestasi belajar matematika dan memiliki koefesien korelasi sebesar 0,593. Hal ini menunjukan bahwa bila seorang siswa mempunyai kemampuan numerik yang baik maka akan mempunyai prestasi belajar matematika yang baik pula. Kemampuan numerik memberikan pengaruh terhadap prestasi belajar matematika sebesar $\quad 35,17 \%$. Hasil pengujian hipotesis koefesien korelasi didapat bahwa terdapat hubungan yang signifikan antara kemampuan numerik dengan prestasi belajar matematika kelas XI IPA SMA se Kabupaten Bogor.

Pengaruh kemampuan numerik (X2) terhadap prestasi belajar matematika (Y) siswa kelas XI IPA SMA se Kabupaten Bogor dapat dinyatakan dalam persamaan regresi linear $\mathbf{Y}$ atas X2 yaitu $\mathbf{Y}=\mathbf{2 1 , 8}+\mathbf{0 , 3 8 4} \mathbf{X 2}$. Dengan koefesien dari X2 bernilai positif yaitu $(+0,325)$, berarti setiap penambahan satu skor kemampuan numerik akan menambah prestasi belajar matematika sebesar 0,384 . dengan skor terkecilnya adalah 21,8 . Dengan demikian dapat diartikan bahwa peningkatan skor prestasi belajar matematika dipengaruhi oleh kemampuan numerik, atau dengan kata lain bahwa makin baik kemampuan numerik seorang siswa akan makin baik pula prestasi belajar matematikanya. Hasil pengujian hipotesis tentang kelinieran regresi dan keberartian koefesien regresi didapat bahwa persamaan $\mathbf{Y}=\mathbf{2 1 , 8}+\mathbf{0 , 3 8 4} \mathbf{X} 2$ berbentuk linier dan koefesien regresinya signifikan (nyata/berarti).

Jadi Hipotesis penelitian yaitu: "Terdapat pengaruh antara kemampuan numerik dengan prestasi belajar matematika siswa" telah terbukti.

\section{Pengaruh Antara Kemampuan Abstrak (X1) dan Kemampuan Numerik (X2) Terhadap Prestasi Belajar Matematika (Y)}

Penelitian secara empiris yang dilakukan terhadap 300 orang siswa Kelas XI IPA se Kabupaten Bogor menunjukan hubungan yang positif dan signifikan antara kemampuan abstrak dan kemampuan numerik dengan prestasi belajar matematika, memiliki koefesien korelasi sebesar 0,691. Hal ini menunjukan bahwa bila seorang siswa mempunyai kemampuan abstrak dan kemampuan numerik yang baik maka akan mempunyai prestasi belajar matematika yang baik pula. Kemampuan absrak dan kemampuan numerik secara bersama-sama memberikan pengaruh terhadap prestasi belajar matematika sebesar $\quad 47,75$ $\%$. Ini menunjukan hampir separuh dari prestasi belajar matematika siswa kelas XI IPA SMA se Kabupaten Bogor dipengaruhi oleh kemampuan abstrak dan kemampuan numerik dari siswa itu sendiri.

Hasil uji hipotesis dengan menggunakan uji F didapat nilai $\mathrm{F}$ hitung sebesar 119,5 $>$ 3,02 dengan tingkat signifikan 5\% atau 0,05 ini membuktikan terdapat korelasi yang signifikan antara kemampuan abstrak dan kemampuan numerik dengan prestasi belajar matematika. Pengaruh kemampuan abstrak dan kemampuan numerik terhadap prestasi belajar matematika dapat dinyatakan dalam persamaan regresi $\mathrm{Y}$ atas $\mathrm{X} 1$ dan $\mathrm{X} 2$ yaitu: $\mathbf{Y}$ $=\mathbf{1 0 , 1 3}+\mathbf{0 , 2 0 5} \mathrm{X} 1+\mathbf{0 , 2 8} \mathrm{X} 2$. Dengan koefesien dari X1 dan X2 bernilai positif, berarti setiap penambahan satu skor kemampuan abstrak dan kemampuan numerik akan menambah prestasi belajar matematika sebesar 0,485. dengan skor terkecilnya adalah 21,8 .

Dengan demikian dapat diartikan bahwa peningkatan skor prestasi belajar matematika dipengaruhi oleh kemampuan abstrak dan kemampuan numerik, atau dengan kata lain bahwa makin baik kemampuan abstrak dan kemampuan numerik seorang siswa akan makin baik pula prestasi belajar matematikanya 
Hasil uji kelinieran regresi dengan menggunakan uji $\mathrm{F}$ didapat nilai $\mathrm{F}$ hitung 118,96 ini menunjukan bahwa regresinya model regresi linier. Dengan demikian dapat disimpulkan bahwa kenaikan skor prestasi belajar matematika seorang siswa dipengaruhi oleh kenaikan skor kemampuan abstrak dan kemampuan numerik dari siswa itu sendiri. Atau bertambahnya skor kemampuan abstrak dan kemampuan numerik akan meningkatkan skor prestasi belajar matematika. Jadi Hipotesis penelitian yaitu: "Terdapat pengaruh antara kemampuan abstrak Dan kemampuan numerik dengan prestasi belajar matematika siswa" telah terbukti.

\section{KESIMPULAN}

Berdasarkan hasil analisis data, maka diperoleh kesimpulan sebagai berikut:

1. Hasil perhitungan analisis korelasi menunjukan adanya hubungan positif antara motivasi belajar dengan prestasi belajar dengan koefesien korelasi $\mathbf{r 1}=\mathbf{0 , 6 9 7}$ artinya terdapat korelasi yang cukup berarti antara motivasi belajar dengan prestasi belajar dengan koefesien penentu $\mathrm{KP}=48,6 \%$ menunjukan bahwa motivasi belajar memberikan pengaruh sebesar 48,6\% terhadap prestasi belajar pengaruh motivasi belajar (X1) terhadap prestasi belajar (Y) dapat dinyatakan dalam persamaan regresi $\mathrm{Y}=\mathbf{2 0 , 5 1 1}+\mathbf{0 , 5 8 7} \mathbf{X 1}$, ini menunjukan bahwa setiap kenaikan satu nilai motivasi belajar dapat meningkatkan prestasi belajar sebesar 0,587. Dari uji signifikan koefesien regresi didapat nilai sig= 000 ini menunjukan motivasi belajar memberikan pengaruh yang sinifikan terhadap prestasi belajar sehingga dapat disimpulkan bahwa Ho ditolak atau H1 diterima, berarti ada pengaruh yang signifikan antara motivasi belajar dengan prestasi belajar

2. Hasil perhitungan analisis korelasi menunjukan adanya hubungan positif antara kemampuan numerik dengan prestasi belajar dengan koefesien korelasi $\mathbf{r} \mathbf{2}=\mathbf{0 , 5 9 3}$ artinya terdapat korelasi yang cukup berarti antara kemampuan numerik dengan prestasi belajar Dengan koefesien penentu KP $=35,17 \%$ menunjukan bahwa kemampuan numerik memberikan pengaruh sebesar $35,17 \%$ terhadap prestasi belajar Pengaruh kemampuan numerik (X2) terhadap prestasi belajar (Y) dapat dinyatakan dalam persamaan regresi, $\mathbf{Y}$ $=\mathbf{2 1 , 8}+\mathbf{0 , 3 8 4} \mathbf{X 2}$, ini menunjukan bahwa setiap kenaikan satu nilai kemampuan numerik dapat meningkatkan prestasi belajar sebesar 0,384. Hasil Uji Z didapat Zo $>$ Zt atau 10,25 $>$ 1,96, sehingga dapat disimpulkan bahwa Ho ditolak atau H1 diterima, berarti ada pengaruh yang signifikan antara kemampuan numerik dengan prestasi belajar

3. Hasil perhitungan analisis korelasi menunjukan adanya hubungan positif antara motivasi belajar dan kemampuan numerik dengan prestasi belajar dengan koefesien korelasi $\mathbf{r 1 2 y}=$ 0,691 artinya terdapat korelasi yang cukup berarti antara motivasi belajar dan kemampuan numerik dengan prestasi belajar Dengan koefesien penentu KP $=47,75 \%$ menunjukan bahwa motivasi belajar dan kemampuan numerik memberikan pengaruh sebesar 47,75\% terhadap prestasi belajar Pengaruh motivasi belajar (X1) dan kemampuan numerik (X2) terhadap prestasi belajar (Y) dapat dinyatakan dalam persamaan regresi, $\mathbf{Y}=\mathbf{1 0 , 2}+\mathbf{0 , 2 0 5}$ $\mathbf{X 1}+\mathbf{0 , 2 8 0} \mathbf{X 2}$, ini menunjukan bahwa setiap kenaikan satu nilai motivasi belajar dan satu nilai kemampuan numerik dapat meningkatkan prestasi belajar sebesar 0,205 +0,280, atau sebesar 0,485. Dari hasil uji hipotesis koefesien korelasi didapat Fo $=119,5$ sedangkan Ft1 $=$ 3,04 dan Ft2 = 3,02 dengan demikian Fo > Ft, sehingga dapat disimpulkan bahwa Ho ditolak atau $\mathrm{H} 1$ diterima, berarti ada pengaruh yang signifikan antara motivasi belajar dan kemampuan numerik dengan prestasi belajar siswa kelas XI IPA SMA Negeri se Kabupaten Bogor. Dari hasil uji hipotesis kelinieran regresi didapat $\mathrm{Fh}=118,96$ sedangkan $\mathrm{Ft} 1=3,04$ dan $\mathrm{Ft} 2=3,02$ dengan demikian $\mathrm{Fo}>\mathrm{Ft}$, sehingga dapat disimpulkan bahwa Ho ditolak atau $\mathrm{H} 1$ diterima, berarti regresinya berbentuk regresi linier. Dengan nilai $\mathrm{P}=0,000<0,05$ maka disimpulkan bahwa koefesien regreasinya signifikan (berarti) 


\section{DAFTAR PUSTAKA}

Aunurrahman. 2009. Belajar dan Pembelajaran. Bandung: Alfabeta

Arikunto Suharsimi. 2007. Evaluasi Program Pendidikan. Jakarta: Bumi Aksara

Baharuddin. 2007. Teori Belajar dan Pembelajaran. Yogyakarta: Ar-Ruzz Media

Baharuddin. 2007. Psikologi Pendidikan. Yogyakarta: Ar-Ruzz Media.

Dimyati, Mudjiono. 2006. Belajar dan Pembelajaran. Jakarta: Rineka Cipta

Hasan Iqbal. 2006. Analisis Data Penelitian dengan Statistik. Jakarta:Bum Aksara

Helmi Dyan R. 2009. 12 Permainan Untuk Meningkatkan Inteligensi Anak. Jakarta: Visi Media

Muhibbin Syah. 2010. Psikologi Pendidikan. Bandung: Remaja Rosdakarya

Morin Edgar, 2005. Tujuh Materi Penting bagi Dunia Pendidikan. Yogyakarta: Kanisius

Prasetyono Dwi Sunar. 2008. Bimbingan \& Pelatihan Tes IQ dan Kepribadian Anda. Yogyakarta: Diva Press

Riyanto Yatim. 2001. Metodologi Penelitian Pendidikan. Surabaya: SIC

Santoso Gempur. 2007. Metodologi Penelitian Kuantitatif dan Kualitatif. Jakarta: Prestasi Pustaka Publisher

Sardiman A.M,. 2003. Interaksi Motivasi Belajar Mengajar. Jakarta: Raja Grafindo Persada.

Soemanto Wasty. 2006. Psikologi Pendidikan. Jakarta: Rineka Cipta

Sudijono Anas. 2001. Pengantar Evaluasi Pendidikan. Jakarta: Raja Grafindo Persada

Sudjana. 2005. Metode Statistika. Bandung: Tarsito

Sunarto. 1999. Perkembangan Peserta Didik. Jakarta: Rineka Cipta

Wirartha I Made. 2006. Pedoman Penulisan Usulan Penelitian, Skripsi, dan tesis. Yogyakarta: CV. Andi Offset

Wulandari Dini. 2009. Super Referensi Tes. Jakarta: Wahyu Media 